botanic gardens of the time. Plant collectors were despatched to various countries, the first being Francis Masson, who went to South Africa in I 772.

After the death of George III. as well as that of Banks in 1820 , the gardens gradually declined in efficiency and repute, until at the accession of Queen Victoria there was a serious danger of their disappearance altogether as a botanic establishment. However, a committee of inquiry, headed by John Lindley, reported strongly in favour of their continuance and further development, and in I840 their control was vested in the Commissioners of Woods and Forests. In $184 \mathrm{I}$, Sir William Hooker was appointed director, and thus was inaugurated the second great period in the history of Kew.

During the last eighty years the area devoted to botany and horticulture has increased from about I5 acres to 288 acres. Its work as the botanical centre of the British Empire and for the distribution of economic plants to all our colonies and possessions is well known. To the public generally it is, of course, best known as a popular resort. Nor must its place as a training school in horticulture be forgotten, especially for curators of Colonial and Indian Botanic Gardens and superintendents of public parks at home. No better testimony of its value to the Empire can be adduced than that of Joseph Chamberlain, then Colonial Secretary, in the House of Commons on August 2, I898: "I do not think it is too much to say that at the present time there are several of our important colonies which owe whatever prosperity they possess to the knowledge and experience of, and the assistance given by, the authorities at Kew."

In pure botany its chief work has been the preparation and publication of Floras of British possessions-a botanical survey of the Empire. Bentham and Hooker prepared their "Genera Plantarum" at Kew, and the monumental "Index Kewensis" was compiled there. The Herbarium contains some 2,500,000 specimens and the library upwards of 24,000 volumes.

Turning to the more conspicuous objects in the accompanying illustration, the one that catches the eye first is the Pagoda (A). This was erected by Sir
William Chambers in $176 \mathrm{I}-2$; it has ten storeys and is 163 feet high. From its summit the Crystal Palace is usually visible and, with a favourable atmosphere, Windsor Castle. During the coal strike in the spring of last year all the more lofty buildings as far as St. Paul's could be seen.

The Temperate House (B) is a structure of three main compartments, the large central one, built in 1862 , being devoted largely to the cultivation of Australian and New Zealand trees and shrubs, the smaller ones, built $1897-1899$, to Himalayan and subtropical ones. The North Gallery (D) contains 848 paintings of flowers and tropical and subtropical vegetation by the late Marianne North; both the paintings and the buildings were presented by her to Kew in I882. The Flagstaff (E), which appears merely as a dark streak in the illustration, was presented by British Columbia, and is $2 \mathrm{r}_{4}$ feet high, 2 feet 9 inches in diameter at the base, I foot in diameter at the summit; at the time of its erection in October r9I9 it weighed 18 tons.

The Palm House $(F)$, where tropical plants, such as palms, cycads, pandanads, bamboos, and bananas, are grown, is an iron structure built $1844-1848$. It is 362 feet long and 66 feet high in the centre. The Orangery $(\mathrm{H})$ is one of Chambers's buildings and was erected in $176 \mathrm{r}$. The orange trees originally housed there were transferred to Kensington Palace in $\mathrm{r} 84 \mathrm{r}$, soon after Kew became public property. It is now known as Museum III. and contains exhibits of exotic timber and miscellaneous objects.

Kew Palace (I), once known as the Dutch House, is a red brick, Jacobean dwelling, built by Samuel Fortrey i63r. By his grandson it was sold to Sir Richard Levett, who was Lord Mayor of London in 1700 , and in I78I it was purchased from the Levetts by George III., who used it as a dwelling for himself and his large family when the Court was at Kew. His sons, the Dukes of Clarence and of Kent, were married in one of the rooms, and his wife, Queen Charlotte, died there November I7, I8r8. It is now open to the public who visit the Gardens, but is not attached in any scientific sense to the establishment, containing only mementoes of the Royal Family.

\title{
Obituary.
}

\section{Dr. R. H. CODRING'TON.}

T $N$ the fulness of years, at the age of ninety-two, Dr. R. H. Codrington, the apostle of Melanesia, has passed away. After a distinguished Oxford career he became Fellow of Wadham; soon after, he joined Bishop Patteson and afterwards lived with Bishop Selwyn at Norfolk Island. After thirty-two years' service in the Melanesian mission he returned to England and became vicar of Wadhurst and Prebendary of Chichester. A friend who knew him well describes him as "the soundest of scholars, kindliest of teachers, most practical of saints, most genial and tolerant of friends." He will be remembered as the first and greatest ethnologist and linguist who studied the people of Melanesia. His fame rests on two great books-"The Melanesian Languages," and "The Melanesians, their Anthropology and Folk-lore," published by the Oxford Press in $1855^{-1891}$. The former laid the foundation of the scientific knowledge of the speech of that region; the second is invaluable to the anthropologist as giving the first and fullest account of religious beliefs. Dr. Codrington was also the discoverer of the principle of Mana, which has played a leading part in the exploration of savage religion since he made it known to the world.

THE Chemiker Zeitung for September 5 announces the death on August 7 of Prof. Emilio Noelting, for many years Director of the Chemical School at Mülhausen. Prof. Noelting was an authority on dye-stuffs; he was born on June 8, I85 $\mathrm{I}$, at Porta Plata, San Domingo, and after study at Zürich he took up his position at Mülhausen in I880 In the issue for September 9 of the same journal the death is announced of Prof. E. Bergmann. director of the Chemisch-Technische Reichsanstalt, Berlin. 